\title{
Borderless Market legislation practice in EU and USA: Competence of central authorities in the federal model
}

\author{
Klaudia Galka
}

\section{Introduction}

There are interesting parallels, which can be drawn between the United States of America (USA) and the European Union (EU) with respect to their federal organization. First and foremost, a borderless market is central to both the US and the EU. Over a period of more than two centuries, the United States' Constitution of 1787 , has led the US market to become one of the best examples of highly integrated markets in the world.

The US have been explicitly concerned with nation-building since their formation over two hundred years ago. Their experience - and thus maturity - suggests that they are now at what Maduro refers to as the "market maintenance" stage: the federal regime has already reached the status quo which it wishes to maintain and this permits a lighter federal hand on the tiller. ${ }^{~}$ This status quo is one that the European Union has been trying to achieve since its creation. After the signing of the Maastricht Treaty in 1992, the Single Market has been deemed to be completed, which gave incentives within the European Union to deepen its further economic and political integration.

The significant differences between both systems in length of existence as well as nature of inception show that the European Internal Market is still in its early stages of integration and its development will remain an ongoing process in the future. In spite of these differences, however, the general progress of the Union toward increased "federalism" seems as persistent and steady as it once was in the United States.

One remarkable observation in particular is that the powers of the central legislature in the area of intrastate commerce in the EU are very similar to those in the USA. The aim of this comparative study is to closely scrutinize these powers of federal legislators, specifically in this field of intrastate commerce. Focusing on positive integration, I will analyze which

$1 \quad$ Barnard 2009, p. 578. 
level of governance in European Union is the most effective to maximize social welfare in the overall economy. Positive integration entails the approximation of laws and standards at the European level in which Article 114 of the Treaty on the Functioning of the European Union (TFEU) plays the most important role. The scope of this provision is thus of crucial importance.

In order to analyze this issue I will try to answer these questions: "Is the scope of the counterpart of the American Commerce Clause, namely Article 114 of TFEU of purely economic meaning, and if so, should it remain purely economic or develop further to achieve a competitive internal market fit for the global arena by also taking the social welfare of European citizens into account?"

Both the EU and the USA have a federated structure with some competencies and responsibilities resting at the central level, some resting with the state governments. Both systems subscribe to a constitutional principle of enumerated powers under which, in order for powers to belong properly to the federal level, they need to have been enumerated as such. The United States Constitution centralized the government with all due respect to a relationship between central government and the state level (amendment $\mathrm{X}$ of the U.S. Constitution ${ }^{2}$ ). In this study, the current American federal model will be compared to the model of governance in Europe which might be considered to be developing towards a federal system. This system essentially implies the supremacy of the (respective) constitution and, indeed, all the hallmarks of American federalism are included in the European Constitution. The Single Market encompasses the respect for EU basic legal principles, subsidiarity and proportionality (Article 5 TEU). However, the European Constitution remains problematic in the European Union. The 2004 attempt to pass the Constitution turned out to be a failure and slowed down further political integration.

Constitutional issues will also be discussed from the judiciary point of view which is to be confronted with political aspects. The important question to be addressed here is the role of judicial control in the process of creating a coherent doctrinal framework. The question whether the legislative acts are immune from legislative review provided that matter falls within the Treaty competences conferred on the EU by the Member States, or in the U.S. Constitution respectively, will be examined.

2 States have all powers that are not specifically granted to the federal government, or forbidden to them under the Constitution. 
Both the EU and the USA have as the main objective to create an internal market. The functional similarities between Article 114 TFEU and Commerce Clause are worth examining as both are specifically important tools in the hands of European and American legislators. In the USA, the federal government can regulate interstate commerce pursuant to the Commerce Clause of the Constitution but in theory, has no power to regulate commerce that occurs only within a single state. The power to regulate commerce is no small power, and in this area the European Union often regulates undertakings in ways that are at least as federal as the United States. The question to what extent this power can be regarded as exclusive, depriving the states of power to legislate whatever is deemed to fit under interstate commerce clause, needs to be revisited. The process of defining limits for legislative competence is a very complex and dynamic one which depends very much on political will. The regulation of commerce through legislation seems to be similar in both systems. In spite of the different backgrounds, USA and EU systems might converge toward the same intrastate level of internal market integration. The comparison of the federalism stage in the area of regulation of commerce in the United States and Europe is a good example of similar solutions in both models. In this paper, I will make a comparative analysis of the impact of internal market provision, mainly Article 114 of the TFEU, and US Interstate Commerce clause on the functioning of systems in relation to their federal features.

In order to answer the aforementioned questions arising in relation to the scope of the Commerce Clause and Internal Market provision, I will compare the federated features of both systems, which many academics and scholars debated. My main focus will be the influence of the federalist governance model on the well-functioning of the internal market. I will start with the reflection on how Commerce Clause, the powerful legal provision, which enabled passing numerous laws at the federal level, has been used in the past by the American legislature. In this respect, I will focus on the wording of Article 114 of the TFEU and its similarity with the Commerce Clause by comparing the case law of the ECJ and the U.S. Supreme Court on the matter in question. Not only the legislature but also judiciary plays an important role in the subject at hand. Therefore, the American federal experience seems particularly relevant to the European integration process in light of the judiciary's contribution to the promotion of legal integration. The leniency and the limits of judicial reviews in both systems compared on the grounds of case law will be an important point of discussion. In my opinion, it is crucial to draw conclusions on this subject to realize where the Internal Market might head and where it is heading to. 


\section{Historical Context: models for their epochs}

Within legal scholarship, drawing a comparison between the federal system of the United States and the 'multi-level' system of the European Union is precarious since the characterization of the European Union as a federal system continues to be rejected by some. ${ }^{3}$ However, both the USA and Europe had emerged from a war and begun to erect a framework for a post-war world. I believe that the crucial difference between the US and the EU to be borne in mind while doing a comparative study, is that in the former sovereignty is seen to lie with the people, while in the latter it is still largely attributed to the state. This observation directly leads to the question on levels of governance. American federal authority was built upon an indigenous American ideology which properly may be termed federal democracy. ${ }^{4}$ The people of the United States have directly constituted themselves both in the States and the United States. Some American authors add that this relatively young American identity at its base is rooted in fear of disunity. Consequently, government at both levels - each in its own sphere, of course - is assumed to exercise that sovereignty, vis-à-vis the people directly. This is what is known as 'dual sovereignty'.5

For post-World War II Europe, on the other hand, it soon became apparent that the federation was too great a step. ${ }^{6}$ The EU could have been described at its inception as a system of 'single sovereignty'. The European Union, and its institutions, is essentially the product of international treaties entered into by the individual MS acting in sovereign capacity. The EU emerged as a 'coming together' polity, leading to an 'ever closer union' of nation-states. ${ }^{8}$ It can be said, therefore, that both models can be seen as the best federal featured solutions possible for the epochs in which they were created. Each has created the type of economy that fits their values and each could learn a little from the other.

For that reason, the nature of their respective unions remains different in light of the democratic aspect. While the EU, like the USA, contemplates government at both the State and the Union level, the relationship between the peoples of Europe and the EU is still not the direct and immediate one that characterizes the relationship between Americans and the United States.

\footnotetext{
3 Van Zeben, p. 4.

4 Nicolaïdis \& Howse 2001, p. 34.

5 Ibid.

6 Nicolaïdis \& Howse 2001, p.35.

7 Ibid.

8 Swenden 2004, p. 380.
} 


\section{USA - the outer boundaries of Congress's commerce power}

\subsection{The principle of federalism}

A unique feature of Unites States is the federal system of government guaranteed by the Constitution and implicit in the very name of the country. Federalism divides constitutional authority and political power between the national government and the states. ${ }^{9}$ Tocqueville considered the division of powers between the federal and state level one of the key virtues of the American legal and political system. ${ }^{10}$ The original theory behind the US Constitution was that the natural operation of centrifugal political forces would ensure that the objectives of national policy remained defined and limited." The national government is restricted to an enumerated set of powers. As Jameson Madison wrote, "the powers delegated by the proposed Constitution to the deferral government are few and defined. Those which are to remain in the State governments are numerous and indefinite." ${ }^{2}$ Inspired by Montesquieu's arguments on the virtues of the separation and division of powers, the American Founding Fathers drew strict dividing lines between the powers of the United States government and the state governments, as well as between the branches of government. This constitutionally mandated division of authority "was adopted by the Framers to ensure protection of our fundamental liberties."13 "State sovereignty is not just an end in itself. Rather, federalism secures to citizens the liberties that derive from the diffusion of sovereign power".14 "Just as the separation and independence of the coordinate branches of the Federal Government serves to prevent the accumulation of excessive power in any one branch, a healthy balance of power between the States and the Federal Government will reduce the risk of tyranny and abuse from either front. ${ }^{15}$ Given the political philosophy underlying American history, the fact that some people now seem to view the fifty states as dependent subdivisions of a national government, with no sovereignty of their own and no distinctive constitutional law worth

9 Fisher \& Harriger 2009, p.333.

11 Nagel, p.15.

Gregory v. Ashcroft, 501 U.S. 452, 458 (1991). 
exploring ${ }^{16}$ points out the development of the federal idea over the ages. The expansion of the role of the central government gradually expanded its jurisdiction into all areas of life, through the open-ended nature of some of the core power-conferring provisions. Some enumerated powers are broad enough to allow congressional control over any aspect of human affairs. The commerce clause jurisprudence stands out in this context.

\subsection{Commerce Clause}

Commercial friction among the states during the 1770 s and 1780 s generated pressure for stronger national powers. The Continental Congress had no power to raise revenue or to regulate commerce among the states. Its power to conclude treaties with foreign nations meant little unless it could control commerce coming into state ports. With each state guarding its sphere of sovereignty, 13 conflicting systems of commercial regulation and duty schedules governed trade in the country. These commercial disputes led to the Annapolis Convention in 1786 and the Philadelphia Convention a year later. ${ }^{17}$ Among the enumerated duties given to Congress was the power to "regulate commerce with foreign nations, and among the several States, and with the Indian tribes." ${ }^{18}$ The Commerce Clause has produced many collisions between the legislative and judicial branches, often pitting the power of Congress to advance its national agenda against judicial constraints that favoured business or state interests. Although the Court in many instances blocked national efforts to regulate the economy, over the long run a persistent Congress prevailed with its independent interpretation of the Commerce Clause.

This section of the study will be organized around the major ideological shifts in American history. The analysis only touches upon the federalism decisions that are considered the major ones by the leading texts and general treatises on constitutional law.

\subsection{Nationalization of the economy}

In light of the nation's experience under the Articles of Confederation, there was a consensus after the adoption of the Constitution that the federal government should be able to exercise national authority to facilitate a national market. The Court's federalism decisions in this period relentlessly pursued this developmental objective, but without violating the original promise that state governments would be left free to follow local

16 Chief Justice Rehnquist observed in United States v. Lopez, 514 U.S. 549 (1995).

17 Fisher \& Harriger 2009, p. 315.

18

Art. 1, 8, CL. 2. 
developmental policies. ${ }^{19}$ National and state governments had mutually exclusive powers, within their own spheres they were supreme and independent.

Under Chief Justice Marshall, the Supreme Court extended broad support to congressional efforts to exercise its commerce powers. The foundation case of US Commerce Clause jurisprudence is Gibbons v. Ogden ${ }^{20}$ in which the Court struck down a New York law requiring a license to operate steamboats between New York City and New Jersey, on the ground that the license was inconsistent with a federal statute regulating 'ships and vessels to be employed in the coasting trade and fisheries'. Chief Justice Marshall clarified the scope of the commerce clause and its application to navigation: "The subject to be regulated is commerce...Commerce, undoubtedly, is traffic [buying, selling or the interchange of commodities,] but it is something more: it is intercourse. It describes the commercial intercourse between nations, and parts of nations, in all its branches, and is regulated by prescribing rules for carrying on that intercourse." The Commerce power is "the power to regulate; that is, to prescribe the rule by which commerce is to be governed. This power, like all others vested in Congress, is complete in it, may be exercised to its utmost extent, and acknowledges no limitations, other than is prescribed in the constitution."

To give content to Gibbons' vision, federal courts thus developed a doctrinal test to distinguish between laws that "directly" affected interstate commerce and laws that affected it only "indirectly." The former were proper objects of federal regulation whereas the latter proper objects of state regulation. ${ }^{21}$

Fundamental changes in economic structures after the Civil War gradually washed away many traditional boundaries between intrastate and interstate commerce. Judicial doctrines of dual federalism and concurrent powers lost ground to a gradual centralization of authority in the national government. ${ }^{22}$ By the end of the nineteenth century, the Court attempted to restrain Congress, but a variety of judicial doctrines did little more than slow the growth of national power. Perhaps the most significant case was Carter v. Carter Coal Co., ${ }^{23}$ in which the Court invalidated the Bituminous Coal Conservation Act's regulation of

\footnotetext{
19 Eskridge \& Ferejohn 1994, p. 1354.

20 Gibbons v. Ogden 22 U.S. 1 (1824).

21 Claeys 2002, p. 410.

22 Fisher \& Harriger 2009, p.324.

23 Carter v. Carter Coal Co., 298 U.S. 238 (1936).
} 
maximum hours and minimum wages in coal mines. In United States v. A.L.A. Schechter Poultry Corp. ${ }^{24}$, the US Supreme court ruled that there is a view of causation that would obliterate the distinction between what is national and what is local."

\subsection{The New Deal Watershed}

The New Deal inverted the basic orientation of Commerce Clause doctrine. ${ }^{25}$ Gone was the restrictive view of the commerce power embodied in Schechter and Carter; in its place appeared a case-by-case inquiry whether a regulated intrastate activity "affect[ed] commerce in such a close and intimate fashion as to be subject to federal control." ${ }^{26}$ Since businesses "affected with a public interest" or with a substantial relation to interstate commerce may be regulated by Congress. Relying on the spending power, Congress makes grants to states and imposes conditions on those funds. Congress may pre-empt state regulation but, until it does, states may regulate with standards that differ from federal requirements. The Court got around to articulating a doctrine of restraint: it would no longer analyze whether a statute fell within the Commerce Clause, but only whether Congress had a "rational basis" to think that the statute fell within the Commerce Clause. ${ }^{27}$ Commerce Clause jurisprudence entered its modern era when in 1937 in NLRB v. Jones \& Laughlin Steel Corpn, ${ }^{28}$ the Court upheld the National Labor Relations Act's regulation of unfair labor practices. In departing from the direct/indirect distinction the Court held that intrastate activities that "have such a close and substantial relation to interstate commerce that their control is essential or appropriate to protect that commerce from burdens and obstructions" were within Congress's power. ${ }^{29}$ The effects test "must be considered in the light of our dual system of government and may not be extended so as to embrace effects upon interstate commerce so indirect and remote that to embrace them ... would effectively obliterate the distinction between what is national and what is local".30

In this era, Congress developed its own independent view of federal-state relations. The meaning of federalism has been shaped more by Congress than by the courts. As the Supreme

\footnotetext{
24 United States v. A.L.A. Schechter Poultry Corp, 295 U.S. 495, 554 (1935).

25 Clayes 2002, p. 425.

26 NLRB v. Jones \& Laughlin Steel Corp., 301 U.S. 1, 32 (1937).

27 Althouse 1996, p.808.

28 NLRB v. Jones \& Laughlin Steel Corp., 301 U.S. 1, 37 (1937).

29 Howells 2002, p. 606.

$30 \quad$ NLRB v. Jones \& Laughlin Steel Corp., 301 U.S. 1, 37 (1937).
} 
Court noted in 1946:"The history of judicial limitation of congressional power over commerce, when exercised affirmatively, has been largely one of retreat than of ultimate victory." ${ }^{31}$

Since 1937, in only two cases the Court has found a federal statute to exceed the scope of the Commerce Clause. In fact, the Court has often enforced the Commerce Clause, but only to invalidate state laws that were deemed to be protectionist or insufficiently justified. The Supreme Court did not strike down a single federal law under the Commerce Clause from 1937 to 1995 . During that period, a large segment of the legal and political communities grew comfortable with the notion that the Commerce Clause gives Congress something close to a general welfare power..$^{32}$ Congress has invoked the Commerce Clause to enact civil rights legislation. A prominent example of the extensive use of the Commerce Clause can be found in the upholding of federal civil rights legislation by which Congress addressed racial discrimination in the 1960s. In the 1964 case of Heart of Atlanta Motel Inc. v. United States33, a motel challenged the constitutionality of the Civil Rights Act of 1964, which put a ban on discrimination of black people in public places, including hotels. The Supreme Court held that Congress could impose such a ban since racial discrimination might deter black people from travelling from one State to another which would in turn affect interstate commerce. Located strategically at an interstate highway near a State border, the motel in question had mostly out-of-State guests. Even if patrons are mostly from within the State, and therefore have not crossed any State borders, it is sufficient that a substantial portion of the food that a restaurant serves comes from other States which again affects interstate commerce. Thus, Congress therefore could legislate under the Commerce Clause to combat racial discrimination. ${ }^{34}$

\subsection{State powers revived}

Beginning in the 1990s, the Supreme Court handed down a number of decisions that revitalized dual federalism. As a 5-4 decision noted in 2002: "Dual sovereignty is a defining feature of our Nation's constitutional blueprint." 35 Some decisions in 2003, 2004, and 2005 seemed to suggest that the era of state powers being revived was waning as the makeup of the court changed. ${ }^{36}$

\footnotetext{
31 Prudential Ins. Co. v. Benjamin, 328 U.S. 408,415.

32 Claeys 2002, p. 407.

33 Heart of Atlanta Motel Inc. v. United States, 379 U.S. 241

34 Kiiver, p.57.

35 Fed. Maritime Company v. S.C. State Ports Auth., 535 U.S. 743, 751 (2002).

36 Fisher \& Harriger 2009, p.334.
} 
In 1995, the Supreme Court struck down the Gun-Free School Zones Act of 1990, which had made it an offence "for any individual to possess a firearm within 1,000 feet of a school.37 The Supreme Court drew a red line between when the commerce clause can be used by the federal legislator and what is too remote from commercial activities. The Court centered on abstruse economic causation questions - whether gun violence near local schools depresses the American economy and held that the Act neither regulates the commercial activity nor contains a requirement that the possession could be connected in any way to interstate commerce. The formal doctrine adopted by the Lopez majority "requires an analysis of whether the regulated activity 'substantially affects' interstate commerce." ${ }^{8}$ The substantial effect test requirement draws a limit - where as a matter of verifiable fact - there is no substantial interest in interstate commerce.

Justice Thomas stood out from the rest for his conservative reading of the Commerce Clause and his disapproval of the modern "substantial effects" test. As Justice Thomas, who favoured returning to this formalistic distinction noted, "despite being well aware that agriculture, manufacturing, and other matters substantially affected commerce, the founding generation did not cede authority over all these activities to Congress" 39 Thomas's approach has the naïve appeal of honesty. He even concedes this boundary drawing may ignore "economic reality" but feels bound to accept this constitutional line. $4^{\circ}$

The Court observed in Lopez that modern Commerce Clause jurisprudence has "identified three broad categories of activity that Congress may regulate under its commerce power." 41 "First, Congress may regulate the use of the channels of interstate commerce." 42 "Second, Congress is empowered to regulate and protect the instrumentalities of interstate commerce, or persons or things in interstate commerce, even though the threat may come only from intrastate activities." 43 "Finally, Congress' commerce authority includes the power to regulate those activities having a substantial relation to interstate commerce i.e., those activities that substantially affect interstate commerce." 44

\footnotetext{
37 Lopez v. United States, 514 U.S. 549 (1995).

38 Lopez v. United States, 514 U.S. at 599.

39 Lopez, 115 S.Ct. at 1642-50 (Justice Thomas, concurring).

40 Howells 2002, p. 606.

41 Lopez v. United States, 514 U.S., at 558.

42 lbid.

43 Ibid.

44 Ibid.
} 
The approach of the majority in Lopez, was affirmed by the Supreme Court five years later, in United States v. Morrison. ${ }^{45}$ Morrison presented a challenge to one provision of the Violence Against Women Act of 1994 which gave a federal civil remedy to the victims of gendermotivated violence. In enacting the law, Congress had found that violence against women because of gender animus affected interstate commerce - by deterring interstate travel, by lost wages and increased medical costs, and reduced demand for goods and services. The Court held the Clause does not cover a statute federalizing the tort of sexual assault." ${ }^{46}$

The concurring majority of the Court itself seems to point out that "depending on the level of generality, any activity can be looked upon as commercial." While it is possible to insist on a conceptual distinction between commercial activities and other kinds of activities, noncommercial behavior usually have large effects on the economy and thus on commercial sales and transportation across state lines. Moreover, even if it were true that some noncommercial activities have no effect in interstate commerce, Congress could (and does) regulate "commerce" in a literal sense when it prohibits the interstate sale and transportation of the goods produced by such activities. Congress can then control the underlying activity by waiving the prohibition on transportation if the activity is carried on in accordance with whatever standards Congress has imposed. A final aspect of the dilemma is that there inevitably are both commercial and noncommercial effects and purposes involved in any wise policy. Therefore, as long as the activity regulated is a part of commerce among the states, pinpointing a noncommercial purpose does not mean that congress is not regulating commerce.

The Gonzalez v. Raich ${ }^{47}$ judgment concerned a challenge to the constitutionality of a federal law, the Controlled Substances Act enacted in 1970 which placed controlled substances - drugs, in short - into five categories and defined exhaustively how, if at all, they may be manufactured, supplied or possessed. A private marijuana possession was classified as an "economic" activity. Justice Stevens reached this conclusion by defining "economics" as "the production, distribution, and consumption of commodities." From

45 In 1994, Christy Brzonkala, a student at Virginia Polytechnic Institute, allegedly was assaulted and raped by two male members of the football team. The two men later allegedly made numerous vulgar remarks about women. Brzonkala alleged that the attack caused her to become emotionally distressed, and soon after she withdrew from the university. After university disciplinary procedures allegedly failed to adequately punish the students, Brzonkala filed suit against the students and the university under the federal Violence Against Women Act (VAWA), which provides a civil remedy for "a crime of violence motivated by gender." 120 S.Ct. 1740 (2000).

46 United States v. Morrison, 529 U.S. 598 (2000).

47 United States v. Morrison, 545 U.S. 1 (2005). 
there, it was easy to conclude that the cultivation and possession of marijuana was "quintessentially economic." Although, the Court never defined "economic" in order to offer guidance to future courts. Of particular relevance to the litigation in this case which had emerged from California, is that the federal act prohibited intrastate noncommercial cultivation and possession of cannabis for personal medical purposes. The Supreme Court upheld the Act stating that regulating purely intrastate or local activity was justified for fear that permitting it would "undercut" the wider interstate régime: that is, the very notion of purely local trade was treated as improbable in a market that is economically integrated. And Congress had a "rational basis" both to find the need to curtail such undercutting and to place the particular targeted ban at stake within the wider scheme of a national regime devoted to drugs generally. ${ }^{8}$ The US Supreme Court also ruled that even local activities can be regulated if there is justified fear that it could undercut the interstate trade.

\section{European Union - the outer boundaries of internal market legislation}

\subsection{The principle of conferred powers}

The general principle is, and always has been, that the EU only has those competences conferred on it by the Member States in the Treaties they signed. This is what is meant by saying that the EU has attributed competence. The EU can only act within the limits of the powers assigned to it. This principle is embodied in Article 5(2) TEU of the Lisbon Treaty, which states that:

Under the principle of conferral, the Union shall act only within the limits of the competences conferred upon it by the Member States in the Treaties to attain the objectives set out therein. Competences not conferred upon the Union in the Treaties remain with the Member States.

There can be disagreement as to the ambit of a particular Treaty Article, and this is so irrespective of the category of competence which applies to the area. Treaty Articles may be drafted relatively specifically, or they may be framed in more broad open-textured terms. In either case, the principles of subsidiarity and proportionality act as power regulators so as

48 Weatherill 2011, p. 860. 
to ensure compliance with this distribution. National parliaments have a role in monitoring compliance with the subsidiarity principle. 49

The issue whether the competence should be exercised is governed by the principle of subsidiarity, which was initially introduced by the Maastricht Treaty. A revised version of the principle is contained in the Lisbon Treaty and a Protocol attached to the Treaty.

"The Community shall act within the limits of powers conferred upon it by this Treaty and of the objectives assigned to it therein." ${ }^{50}$ In precisely this vein the Court in Tobacco Advertising had refused to treat legislative harmonization as creating "a general power to regulate the internal market" because this would be incompatible with the principle that "the powers of the Community [now Union] are limited to those specifically conferred on it." Protocol No 25 on the Exercise of Shared Competences, Declaration No 18 in Relation to the Delimitation of Competences, and the subsidiarity principle combined with Protocol No 1 on the Role of National Parliaments in the European Union also help to convey the image of a stronger check on the use of competences by the EU. ${ }^{51}$ The Court of Justice of the European Union (CJEU) is no different from any federal constitutional court in that it always faces the dilemma of 'resolving legislative conflict about constitutionality, while maintaining or reinforcing the political legitimacy of constitutional review into the future'.52

The Treaty contains an express provision providing for subsidiarity so that in areas not within its exclusive competence the Community shall only act:

"if and insofar as the objectives of the proposed action cannot be sufficiently achieved by the Member States and can therefore, by reason of the scale or effects of the proposed action, be better achieved by the Community". This reflects the view that decisions should be taken as closely as possible to the citizen. The subsidiarity issue did not play a large role in the Court's judgments, but the Advocate General in his advisory opinion had ruled it did not apply as the internal market rules were in any event areas of exclusive Community competence to which the subsidiarity principle did not apply. Since the Lisbon Treaty introduced the classification competence, Internal Market clearly falls within shared competence as delineated in Article 4 TFEU.53

49 Craig \& Burca 2011, p.94.

50 Treaty Establishing the European Community, Dec. 24, 2002, 2002 O.J. (C 325) 33.

51 van Zeben 2012, p. 16.

52 Swenden 2004, p.380.

53 Treaty of Lisbon amending the Treaty on European Union and the Treaty establishing the European Community, 2007/C 306/01. 


\subsection{Internal Market legislation}

The central objective of the EEC Treaty has always been the establishment of a common market. The removal of economic and commercial barriers between the EU Member States has been an aim of the European integration process since the Treaty of Rome was signed in 1958. The common market policy was intended to eliminate trade barriers between Member States with the particular aim of increasing economic prosperity and contributing to "an ever closer union among the peoples of Europe". In accordance with Article 14 of the EC Treaty, the internal market is an area without internal frontiers in which the free movement of goods, persons, services and capital is ensured. The establishment of a customs union in 1968 formed the basis for the construction of a common market in goods in the EC. The stagnation in the 1970 s of the European integration process led to the Cecchini report 'The cost of non-Europe' presented in March 1988.54 The loss of revenue was estimated at a minimum of $4.25 \%$ and possibly as much as $6.5 \%$ of GDP. The European Internal Market project, which was initiated in the mid-1980s with the publication of the White Paper on the Single Market Programme, opened up perspectives for restoring confidence of European business and for improving the performance of European companies through the formation of a better integrated, more competitive and innovative market place. While the Internal Market has contributed to promote integration and to a lesser extent competition within the EU, its potential has not been fully exploited. 55 The process was concluded with the creation of the EU internal market on 31 December 1992 as envisaged by the Single European Act of $1987^{56}$

The Single European Act introduced the legislative innovation which is now to be found in Article 114 TFEU which was Article $95 \mathrm{EC}$ and before that Article 100a EC/EEC. This provision states that any national measure may be harmonized provided that it leads to an improvement in the functioning of the internal market envisaged by Article 26 TFEU. Article 114(2) TFEU excludes from the scope of Article 114 TFEU measures relating to fiscal provisions, the free movement of persons and the rights and interests of employed persons as the British government insisted while drafting. This aimed to exclude a social dimension from the single European market programme. What is of great importance is the switch from the unanimity to the qualified majority voting method for adopting legislation under Article 114 TFEu as legal basis following the SEA which improved the decision-making as to enable the common market to develop. After the Treaty of Lisbon,

54 Cecchini 1988. See also: Giuseppe Gargani 2003.

55

Ilzkovitz et al. 2007, p. 18.

56

Ibid. 
one might argue that given the involvement of the EP and the EESC, an abuse ${ }^{57}$ of article 114 TFEU is less likely to occur. Despite the considerable discussion concerning possible reforms of Article $95 \mathrm{EC}$, especially with regards to the scope of Community competence under this provision, the agreed alterations have been relatively modest. Article 114 empowers enactment of measures including directives and regulations. ${ }^{58}$ Art 114 TFEU is to be treated as lex generalis and operates 'save where otherwise provided in this Treaty'. In the Court's jurisprudence on the scope of Article 114 TFEU, the highpoint to be mentioned is Spain v. Council judgment. The CJEU held there that the harmonization power relative to the internal market in Article 95[Article 114 TFEU] could be used to prevent even any future obstacles to trade or a potential fragmentation of the internal market.59

\subsection{Limits on the Community's harmonization power}

In Tobacco Advertising, the CJEU struck down a directive which harmonized the law relating to the advertising and sponsorship of tobacco products. The directive banned all forms of advertising and sponsorship in the Community with very limited exemptions, for example for diversification products i.e. where the tobacco name had been used for another product, such as Camel boots, communications within the trade, at tobacco outlets and in publications from third countries not principally intended for the Community market. Deferred implementation was permitted in certain circumstances, notably in relation to international sporting events such as Formula One racing. Member States were free to have stricter requirements. ${ }^{60}$

This ruling is of landmark significance and can be seen as an expression of judicial defense of the limits of EU legislative competence against political preference to abuse the limits agreed and approved by national constitutional process at the time the Treaty was drafted and subsequently revised. ${ }^{61}$ Academics emphasized that the judgment signaled an important shift in European federalism and altered the balance of competences between the European Union and its Member States. ${ }^{62}$ The CJEU pointed out that Article

57 Maletić 2009, p.26.

58 Craig \& Burca 2011, p. 590.

59 Case C-350/92, Spain v Council, 1995 E.C.R. I-1985, para. 35.

60 Directive $98 / 43$ /EC of the European Parliament and of the Council of 6 July 1998 on the approximation of the laws, regulations and administrative provisions of the Member States relating to the advertising and sponsorship of tobacco products: OJ 1998 L 213/9.

61 Weatherhill 2011, p. 830.

62 Nicola \& Marchetti 2005, p.515. 
114 TFEU did not, as argued by the Commission, Council, and EP, give any general power of market regulation. This would, said the CJEU, be contrary to Articles $3(1)$ (c) and 14 EC, and be incompatible with the principle in Article $5 \mathrm{EC}$ that the Community's powers were limited to those specifically conferred on it.

The CJEU established the threshold for the judicial review of internal market legislation. First of all, Advocate-General Fennelly held that "the choice of the legal basis for a measure must be based on objective factors which are amenable to review. Those factors include in particular the aim and content of the measure." ${ }^{63}$ The Court held that a measure enacted pursuant Article 95 EC must genuinely have as its object the improvement of the conditions for the establishment and functioning of the internal market. The Tobacco Advertising judgment established that requirement of the impact being substantial, the echo of the wording can be found in the American decision Gonzalez $v$. Raich. If mere disparities between national rules, and the abstract risk of obstacles to the exercise of the fundamental freedoms, or distortions of competition could justify the use of Article $95 \mathrm{EC}$, then judicial review of compliance with the proper legal basis would be rendered 'nugatory'. Those barriers and the improvements in the internal market, which correspond to their removal have to be verifiable. ${ }^{64}$ Even measures intended directly to contribute to the removal of trade barriers are to be supported by some evidence of the existence of such barriers. Any distortion of competition had to be appreciable, since otherwise 'the powers of the Community legislature would be practically unlimited' ${ }^{5}$ Apropos distortion of competition, the judgment makes it clear that the distortion must be "appreciable". The Court does not expand in this way for the barriers to trade limb, but the Advocate General without expanding does suggest that "harmonising action should relate to national rules which have more than trivial effects on trade." The Court found that since tobacco advertising was predominantly local, non-harmonized advertising did not present an appreciable obstacle to trade or unfair competition. The ECJ judgment embraced the opinion of Advocate-General Nial Fennelly, who claimed that differences among the tobacco advertising regulations of Member States did not justify a total ban on tobacco advertising. To summarize, the non-approximated status quo must constitute barriers to cross-border trade, and the legislative act in question must contribute to reducing such barriers, whether ones presently existing or likely to exist in the future. The ECJ has accepted obstacles to the exercise of the fundamental freedoms and appreciable

63 Howells 2002, p.613.

64 Craig \& Burca 2011, p. 591.

65 Case C-376/98 Germany v Parliament and Council [2000] ECR I-8419, para. 83 and 84. 
distortions of competition throughout the EU as barriers to cross-border trade justifying measures of approximation under Article 114 TFEU. Hence, while legislative discretion is not excluded, the subjective view of the European legislature does not reign supreme. It has to be supported by objective reliable data. ${ }^{66}$

\subsection{After Tobacco Advertising}

Following the Tobacco Advertising Judgment, the Tobacco Products Directive 2001/37/EC, which aimed at harmonizing various aspects of the manufacture, sale, and presentation of tobacco products, was challenged. ${ }^{67}$ The Directive was aimed at improving the functioning of the internal market for tobacco products, not media carrying advertisements for tobacco products. The Court, asked to deliver a preliminary ruling by an English court before which questions of validity had been raised in proceedings initiated by tobacco companies, held that Article 95 of the EC Treaty was a valid legal basis for the directive. In its ruling the Court considered that the Directive could be deployed against threats to the market that had already emerged as some Member States adopted new and stricter and, crucially, divergent rules or were "likely to emerge" at the time of its adoption. It was therefore sufficient that distortions were likely to emerge whereas in the Tobacco Advertising Judgment, the ECJ said that the market distortions had to be "appreciable." The fact that the directive also protected public health did not undermine its validity, since intra-Community trade was at stake.

The Court upheld the Directive 2002/46 on food supplements in the Alliance for Natural Health ${ }^{68}$ judgment. The Directive as a measure, harmonizes national rules governing foods containing concentrated sources of nutrients on the basis that legislative diversity at national level harms the functioning of the internal market. The Court's objective review of the impact of regulatory diversity in the internal market is immediately and unavoidably tied to what Member States do and are likely to do and is here shown to be connected to apparently unverified private complaints.

Swedish Match ${ }^{69}$ concerned the validity of the Directive 2001/37 which provides that the Member States are to prohibit the placing on the market of tobacco for oral use.

$66 \operatorname{COM}(2010) 348$ final, p. 16.

67 Case C-491/01, The Queen v. Secretary of State for Health ex parte British American Tobacco (Investments) Ltd., 2002 E.C.R. I-11453.

68 Cases C-154/04 \& C-155/04, Alliance for Natural Health v. Secretary of State for Health, [2005] E.C.R. $1-6451$.

69 Case C-210/03 R v Secretary of State for Health, ex p Swedish Match [2004] ECR I-11893. 
This targets snus, which is tobacco sold loose or in small sachets and intended to be consumed by placing between the gum and the lip. The key element taken into account by the Court was the fact that the market in tobacco products was one in which trade between Member States represents a relatively large part. Given the relatively large amount of inter-state trade in this market, "those prohibitions of marketing contributed to a heterogeneous development of that market and were therefore such as to constitute obstacles to the free movement of goods" and it was "likely" that obstacles to the free movement of those products would arise by reason of the adoption by the Member States of new rules reflecting growing public anxiety. The fact that even the total ban on the marketing product may still be justified under Article 114 TFEU proves the low threshold for review established by the Tobacco Advertising Judgment.

In the Vodafone, $\mathrm{O}_{2}$ et al v. Secretary of State judgment, ${ }^{70}$ the regulation based on Article 114 TFEU introduced a common approach so that users of terrestrial public mobile telephone networks do not pay excessive prices for Community-wide roaming services and so that mobile operators can operate within a single coherent regulatory framework based on objectively established criteria. The CJEU explained that: "According to consistent case-law the object of measures adopted on the basis of Article 95(1) EC [114(1) TFEU] must genuinely be to improve the conditions for the establishment and functioning of the internal market.... While a mere finding of disparities between national rules and the abstract risk of infringements of fundamental freedoms or distortion of competition is not sufficient to justify the choice of Article 95 EC [114 TFEU] as a legal basis, the Community [Union] legislature may have recourse to it in particular where there are differences between national rules which are such as to obstruct the fundamental freedoms and thus have a direct effect on the functioning of the internal market.... Recourse to that provision is also possible if the aim is to prevent the emergence of such obstacles to trade resulting from the divergent development of national laws. However, the emergence of such obstacles must be likely and the measure in question must be designed to prevent them...." ${ }^{71}$

Although European initiatives under Article 114 TFEU must relate to the establishment and functioning of the internal market, the provision will not be automatically unavailable in circumstances where policies other than strictly economic integration, such as public

70 Case C-58/08 The Queen, Vodafone Ltd and Others v Secretary of State for Business, Enterprise and Regulatory Reform 2002 E.C.R. I-11453.

71

Case C-58/08, Vodafone, O2 et al v. Secretary of State, judgment of 8 June 2010, paras. 32-33. 
health considerations, may have encouraged the legislator to adopt a Community norm..$^{72}$ It follows from the foregoing that when there are obstacles to trade, or it is likely that such obstacles will emerge in the future, because the Member States have taken, or are about to take, divergent measures with respect to a product or a class of products, which bring about different levels of protection and thereby prevent the product or products concerned from moving freely within the Community, Article 95 EC[Article 114 TFEU] authorizes the Community legislature to intervene by adopting appropriate measures, in compliance with Article 95(3) EC and with the legal principles mentioned in the Treaty or identified in the case-law, in particular the principle of proportionality.73 Depending on the circumstances, those appropriate measures may consist in requiring all the Member States to authorize the marketing of the product or products concerned, subjecting such an obligation of authorisation to certain conditions, or even provisionally or definitively prohibiting the marketing of a product or products.

In the Inuit Tapiriit Kanatami et al v. Parliament and Council74 second decision, the Court ruled on the validity of the Regulation (EC) No 1007/2009 on trade in seal product. The seal products trade within the EU is permitted 'only where the seal products result from hunts traditionally conducted by Inuit and other indigenous communities and contributes to their subsistence'. The preamble of the Regulation deems to prove that the internal market requires common rules as the 'differences between national provisions governing the trade, import, production and marketing of seal products ... adversely affect[ed] the operation of the internal market in products which contain[ed] or [might] contain seal products, and constitute[d] barriers to trade in such products. In short, the EU bans seal products that are not the product of a traditional hunt in order to secure free movement of seal products which are so obtained. There is nothing in the wording of Article 114 nor in the Court's elaboration of its pre-conditions which excludes such an approach. ${ }^{75}$ Moreover, the Court emphasized that the regulation's principal objective is clearly not to safeguard the welfare of animals but to improve the functioning of the internal market. Furthermore, according to the settled case-law, provided that the conditions for recourse to Article 95 EC[Article 114 TFEU] as a legal basis are fulfilled, the Union legislature cannot be prevented from relying on that legal basis on the ground that the protection of animal welfare is a decisive factor in the choices to be made. Such a situation may be found, by analogy, in relation to public health

72 Maletić 2009, p.5. 
protection. ${ }^{76}$ Therefore, the EU Regulation could be justified as a measure of harmonization beneficial to the internal market as well as a measure concerning animal welfare.

The conclusion is that internal market legislation, to be constitutionally valid, must satisfy a specific internal market test, in the sense that the authors of the act must make a plausible case that the act either helps to remove disparities between national provisions that hinder the free movement of goods, services or persons, or helps to remove disparities that cause distorted conditions of competition. However, these need not be, and cannot logically be, the only purposes of internal market legislation. Such legislation is always also about 'something else', and that something else may, in fact, be the main reason why the internal market measure was adopted. The multi-faceted nature of internal market legislation is one of the inherent characteristics of that legislation and not a perverse ploy of European actors to extend the range of their competences. ${ }^{77}$

\section{Conclusion}

\subsection{Economic globalization}

The EU is the largest economy in the world with a GDP of over 16.5 trillion dollars in 2012 followed by the US economy which generates over 15.7 trillion dollars..$^{78}$ This general picture suggests the growing impact of the EU on international economic co-operation as the EU appears to be both defensive and reactive in the face of global challenges. The visibility and importance of the EU as an actor in world politics has been growing over the years. Despite its lack of statehood the EU has become a credible and legitimate participant in international co-operation, especially in the area of political economy. Incontestably, the Economic and Monetary Union (EMU) had a significant impact on the increase of EU's strategic action capacity in the world political economy.79 The Transatlantic Trade and Investment Partnership on which the negotiations are currently ongoing is the most promising proof of this statement. EU-US economic relations can be linked quite directly with the accumulation of legitimacy on the part of the EU, and particularly the Community institutions.

76 Case T-526/10, Inuit Tapiriit Kanatami et al v. Parliament and Council, order of 25 April 2013, para. 41.

77 de Witte 2006, p. 65.

78 World Economic Outlook Database 2012.

79 See: Smith 1998 
The credibility of the EU has also improved in the eyes of the European citizens. Some authors argue that Europeanization can be viewed in terms of a particular response to globalization. Half of the European citizens believe that the Internal Market as a whole strengthens their country in comparison with other nations such as the USA. ${ }^{80}$ This only strengthens the argument that awareness is growing about the fact that we live in an interconnected economy. The contribution of the Internal Market to the transformation of the EU into a more dynamic, innovative and competitive economy at a global level is, indeed, crucial. It is, therefore, essential that the Internal Market does not only focus on economic effectiveness.

\subsection{Judiciary}

These borderline questions on the scope of the internal market legislation are hard to decide. It is clear that the ECJ draws inspiration from the case law of the US Supreme Court under the Commerce Clause. The history of the judicial struggle to interpret the Commerce Clause during the transition from the economic system the Founders knew to the single, national market still emergent in our own era counsels great restraint before the Court determines that the Clause is insufficient to support an exercise of the national power. American people's evolving conceptions of commerce and their collective national interests are interlinked. In 1930 s during the Depression, the American economy became a new object of the American national political consciousness as people realized they would sink or swim together in the huge national economy. Furthermore, in the US system the decisions are taken by a politically accountable body. Congress can be thrown out by the electorate if it is seen as overstepping the boundary between state and federal activity. The citizens can use electoral processes to defend their interests without judicial intervention.

There may be other good reasons for the Supreme Court taking a more abstentionist role than the ECJ. ${ }^{81}$ The Supreme Court will be more prone to strike down state or local, rather than national, regulation on grounds of federalism. This is so in part because the Court is more likely to diverge ideologically from any given state legislature than it is from Congress, given the political or ideological variability among the states. Moreover, the Court needs the cooperation of Congress to accomplish many of its goals, especially, the smooth functioning of the federal judiciary as a whole. The Court also has more to fear from Congress than from state legislatures: Congress can impeach justices, tinker

80 Internal Market: Awareness, Perceptions and Impacts Report, p. 2.

81 Nicolaïdis \& Howse 2001, p.491. 
with their pensions, refuse to increase judicial salaries to keep pace with inflation, enlarge the size of the Court, arbitrarily add to the Court's workload, leave lower court vacancies unfilled, fiddle with federal jurisdiction, and so forth. ${ }^{82}$ Prominent United States Senators want to deny nominees confirmation if they have the "wrong" views about federalism. ${ }^{83}$ In Garcia, the Court announced that the protection of federalism depends largely on the political process operating within Congress. Judicial fidelity to federalism norms switch cyclically through political eras of American history in accordance with the electoral change in Congress. ${ }^{84}$ It is therefore clear that the debate on limits of Congress's power to legislate under Commerce Clause remains primarily political.

In contrast to the USA, there is a lack of adequate representation in the European Union since the Commission is unelected, Parliament has a power of consultation and at most a possible veto, and the Council is only indirectly accountable through national governments and can impose solutions in areas of majority voting on dissenting states. Therefore, the additional judicial protection seems to be legitimate. However, the assertive role of the CJEU in scrutinizing the internal market legislation could be explained by the roots of the inception of the European Union and dependency on the political will of Member States. The matter is crucial to the speed of European integration, therefore, political institutions are constructed in such a way that nationalizing forces are to be politically, rather than judicially restrained. As it is believed that the idea of limited national power is simply not judicially enforceable.

In Europe, we could not really imagine that the legislation adopted under Article 114 TFEU as legal basis, deals with criminal matters. The main reason behind that, are differently tailored European treaties compared to the American constitution. European Treaties are based on sector-specific rules whereas the American Constitution was amended only twenty seven times throughout its long history.

\subsection{Irresolvable dilemma}

Revisiting one of the key historical objectives of the European integration project should trigger a broader discussion about the values that should characterize the further development of the European Union. Could, or maybe rather, should the internal market

82 Eskridge \& Ferejohn 1994, p. 1367.

83 Clayes 2002, p. 405.

84 The Supreme Court declared that "State sovereign interests are more properly protected by procedural safeguards inherent in the structure of the federal system than by judicially created limitations on federal power": Garcia v. San Antonio Metropolitan Transit Authority 469 US 528, 552 (1985). 
legislative basis be used to govern behaviour in schools or violence against women like American people experienced? Are factors which affect the general welfare of European citizens and hence their ability to participate in those activities, beyond the pale of internal market law in the 21st century? It goes to the heart of the federal question - what does the European internal market entail? Is it still just an area without internal frontiers in which the free movement of goods, persons, services and capital is ensured seen through economic lenses?

Unlike the United States, the European Community was not, and could not have been, founded as a democratic nation state. The European Union has been created as a technocratic federated political model. Undoubtedly, the economic aspect of the internal market has always been the expertise of the Union level. This is in congruence with Arcuri and Dari-Mattiacci's theory ${ }^{85}$ focused on regarding the issue of risk diversification in the choice between centralization and decentralization. They conclude that in case of independent risks, the choice between centralization and decentralization depends on the level of scientific expertise available: if advanced expertise is available, centralization guarantees more accurate decisions and less risk. Contrary to the European Union, the United States is not a social welfare state, but its economy seems to acknowledge that the welfare of the people has substantial impact on the overall economy. In the US, the creation of the internal market preceded and thus largely precluded the development of a welfare state since regulatory competition among state governments practically prevented all of them from adopting regulations, such as those prohibiting the employment of child labour, that would have reduced the competitiveness of the local product. ${ }^{86}$ There however, a solution became available after the New Deal constitutional revolution, when the Supreme Court finally allowed political responsibility for welfare state functions to be exercised at the federal level. ${ }^{87}$

There were good reasons to focus on the economy in the beginning of European integration, since a political union was not achievable through a single big step. But we are way beyond the times of the European Coal and Steel Community. The EU is more than a free trade area, it is also more than an economic or monetary union - today the EU takes

85 Their model shows that centralization more often succeeds at delivering the 'right' decision in terms of policy as compared to decentralized systems due to the possibility of pooling expertise at the central level, ceteris paribus. However, the consequences of an erroneous decision at the centralized level can be global, rather than locally confined. Centralization continues to deliver more accurate results in case of less available expertise but decentralization lowers the risk that comes with an erroneous decision.

86 See F. Scharpf in R. Howse and K. Nicolaïdis 2001, p. 356-7.

87 Scharpf 2010, p. 2. 
decisions that affect every single European citizen in many ways. ${ }^{88}$ As an evolved federal political system, Europe should be an economic, political and social unity. The EU's primary purpose is thus not to complete, defend or govern the Single Market. Its main purpose has to be to serve its citizens. The Single Market is not an end in itself, it is an instrument to foster economic growth and produce wealth for the people. ${ }^{89}$ European economic integration creates conditions of regulatory and tax competition among member states which reduces the capacity of national governments to respond effectively to the demands and expectations of their citizens. Therefore, the scope of internal market legislation should also relate to contemporary ideals, individual rights or good government. That would give real meaning to the idea, expressed in Article 3 TFEU, that the Union should work to establish a "social market" economy, a term which underlines the link between economic and social policy to ensure greater coherence between the two.9 ${ }^{\circ}$

I believe that an internal market which is competitive on the global scale cannot be solely based on economic effectiveness. Economic Order in the European Union should be based not only on economic integration, but also consumer safety, social rights, labour policy and environment. The economic focus has often dominated the European integration, especially until the 1990s. Already in the 1997 Action Plan, the European Commission set forth the strategic target to deliver a single market for the benefits of all citizens. In the introduction, it was expressly stated that 'the single market was not simply an economic structure', but included basic standards of health and safety, equal opportunities, and labour law measures. ${ }^{91}$ Structuring the internal market is nevertheless an ongoing process which must constantly adapt to new economic and political configurations. Certainly, legislature should keep pace with societal changes. Failure to do so may well lead EU citizens to blame the EU for the failure of the European social model..$^{92}$

The comparative study between USA and EU confirms that both systems face similar federal dilemmas. The process of defining limits for legislative competence is a very complex and dynamic problem. The judicial threshold reviews applied in jurisprudence concerning the area of market clearly illustrate that the question on whether or not the social policy should be included in the scope of the Commerce Clause/ internal market keeps

88 See: Jo Leinen 2013

89 lbid.

90 Barnard 2009b, p. 606.

91 Communication from the Commission to the European Parliament and the Council, Mutual Recognition in the Context of the follow-up to the Action Plan for the Single Market, 16 June 1999. 
returning. This observation proves that the federal questions of this nature are impossible to resolve in an uncontroversial manner, but they are cyclical. Depending on the political climate, sooner or later the issue on what kind of internal market we want in Europe, will return. Therefore, the active judicial intervention should not become a norm but rather be exceptional since matters at stake are tightly linked to the assessment of how much centralization European citizens want in Europe. The revolutionary moment for Europe would be if the European citizens actually acknowledge the internal market to be an issue concerning them directly every day. In turn, the European law would then have to adapt to reality and, thus the inclusion of a social policy. 


\section{Bibliography}

\section{Primary Sources:}

\section{European Commission 1999}

- Communication from the Commission to the European Parliament and the Council, Mutual Recognition in the Context of the follow-up to the Action Plan for the Single Market, 16 June 1999.

European Commission 2010

- Policy Options for Progress Towards a European Contract Law Comments on the issues raised in the Green Paper from the Commission COM(2010) 348 final.

\section{Case Law}

\section{United States of America}

- Gibbons v. Ogden 22 U.S. 1 (1824).

- Carter v. Carter Coal Co., 298 U.S. 238 (1936).

- A.L.A. Schechter Poultry Corp. v. United States, 295 U.S. 495, 554 (1935).

- NLRB v. Jones \& Laughlin Steel Corp., 301 U.S. 1, 32 (1937).

- Prudential Ins. Co. V. Benjamin, 328 U.S. 408,415 (1946).

- Heart of Atlanta Motel, Inc. v. United States, 379 U.S. 241, 256 (1964).

- Garcia v. San Antonio Metropolitan Transit Authority 469 US 528, 552 (1985).

- Gregory v. Ashcroft, 501 U.S. 452, 458 (1991).

- United States v. Lopez, 514 U.S. 549 (1995).

- Gonzalez v. Raich 529 U.S. 598 (2000).

- United States v. Morrison, 529 U.S. 598 (2000).

- Fed. Maritime Com'n v. S.C. State Ports Auth., 535 U.S. 743, 751 (2002).

\section{European Union}

- Case C-350/92 Spain v Council 1995 E.C.R. I-1985.

- Case C-376/98 Germany v Parliament and Council [2000] ECR I-2247.

- Case C-491/01 British American Tobacco (Investments) and Imperial Tobacco [2002] ECR I-11453.

- Case C-210/03 Swedish Match UK Ltd v. Secretary of State for Health [2004] ECR I-11893.

- Case C-66/04 United Kingdom v Parliament and Council (Smoke Flavourings) [2005] ECR $\mathrm{I}-10553$. 
- Cases C-154/04 \& C-155/04, Alliance for Natural Health v. Secretary of State for Health, [2005] E.C.R. I-6451.

- Case C-380/03 Germany v European Parliament [2006] ECR I-11573.

- Case C-301/06 Ireland v Parliament and Council [2009] ECR I-593.

- Case C-58/08 Vodafone, O2 et al v. Secretary of State [2010] ECR I-5026.

- Case T-18/10 Inuit Tapiriit Kanatami et al v. Parliament and Council [2010] ECR II-0000.

- Case T-526/10, Inuit Tapiriit Kanatami et al v. Parliament and Council, order of 25 April 2013

\section{Secondary sources}

\section{Althouse 1996}

- Ann Althouse, Enforcing federalism after United States v. Lopez, Arizona Law Review 1996 (38), p. 793- 820

\section{Barnard 2012}

- Catherine Barnard, What the Keck? Balancing the needs of the single market with state regulatory autonomy in the EU (and the US), European journal of consumer law 2012(2), p. 201-217.

\section{Barnard 2009}

- Catherine Barnard, Restricting restrictions: lessons for the EU from the US?, The Cambridge Law Journal 2009 (68), p. 575-606.

\section{Bermann 1994}

- George Bermann, "Taking Subsidiarity Seriously: Federalism in the European Community and the United States" Columbia Law Review 1994 (94), p. 332-435.

\section{Clayes 2002}

- Eric R. Claeys, The Living Commerce Clause: Federalism in Progressive Political Theory and the Commerce Clause After Lopez and Morrison, William \& Mary Bill of Rights Journal 11(1) 2002.

\section{Craig \& De Burca 2011}

- Paul Craig \& Gráinne De Búrca; EU Law Texts, Cases and Materials. (Oxford University Press: Oxford, $5^{\text {th }}$ edition, 2011).

\section{De Witte 2006}

- Bruno de Witte, 'Non-Market Values in Internal Market Legislation' in Niamh Nic Shuibhne (ed.), Regulating the Internal Market, Cheltenham, Edward Elgar, 2006, pp.61-86

\section{Eskridge \& Ferejohn 1994}

- William N. Eskridge Jr. and John Ferejohn, The Elastic Commerce Clause: A Political Theory of American Federalism, Vanderbildt Law Review: Yale Law School, 1994 (47), p. 1355. 


\section{Fischer \& Harriger 2009}

- Louis Fisher \& Katy J Harriger; American constitutional law: volume 1 constitutional structures: separated powers and federalism. (Carolina Academic Press: Durnham, 8th edition, 2009).

Howells 2002

- Geraint Howells, Federalism in USA and EC: The Scope for Harmonised Legislative Activity Compared, European Review of Private Law 2002 (5), p. 601-622.

Maletić 2009

- Isidora Maletić, The boundaries of the Internal Market after the Lisbon Treaty: a closer look at article 95 EC, Croatian Yearbook of European Law and Policy 2009(5), 5.

Nagel 2001

- Robert Nagel, The implosion of American federalism, (Oxford University Press: New York 2001.

Nicola \& Marchetti 2005

- Fernanda Nicola \&Fabio Marchetti, Constitutionalizing Tobacco: The Ambivalence of European Federalism. Harvard International Law Journal, 2005 (46), p. 507-525.

Nicolaïdis \& Howse 2001

- Kalypso Nicolaïdis and Robert Howse (eds), The federal vision: legitimacy and levels of governance in the United states and the European union, Oxford [etc.]: Oxford University Press 2001.

Smith 1998

- Michael Smith , 'Competitive co-operation and EU-US relations: can the EU be a strategic partner for the US in the world political economy?', Journal of European Public Policy 5(4) 1998, p.561-577.

Schütze 2009

- Robert Schütze, From dual to cooperative federalism: the changing structure of European law (Oxford [etc.]: Oxford University Press 2009).

Schütze 2009b

- Robert Schütze,On “federal" ground:the European Union as an (inter)national phenomenon, Common Market Law Review 2009 (46) p. 1069-1105.

Schütze 2010

- Robert Schütze, From Rome to Lisbon: Executive federalism in the (new) European Union, Common Market Law Review 2010 (47) p. 1385-1427.

\section{Swenden 2004}

- Wifried Swenden, 'Is the European Union in need of a Competence Catalogue? Insights from Comparative Federalism', Journal of Common Market Studies 371 (2004). 


\section{Weatherill 2011}

- S R Weatherill, 'The limits of legislative harmonisation ten years after Tobacco Advertising: how the Court's case law has become a "drafting guide"' German Law Journal 2011(12), p. $827-863$.

Wyatt 2007

- Derrick Wyatt, 'Community Competence to Regulate the Internal Market' University of Oxford Faculty of Law Legal Studies Research Paper Series No 9/2007.

\section{Cecchini 1998}

- Paolo Cecchini, The European Challenge 1992: The Benefits of a Single Market, (Aldershot, England: Gower Publishing Company, Ltd., 1988).

\section{Internet Sources:}

\section{Ilzkovitz \& Dierx 2007}

- Fabienne llzkovitz \& Adriaan Dierx et al., Steps towards a deeper economic integration: the Internal Market in the 21st century: A contribution to the Single Market Review, DirectorateGeneral for Economic and Financial Affairs, 2007 Retrieved from:

http://ec.europa.eu/economy finance/publications/publication784_en.pdf, last visited on 11-07-2013.

\section{Internal Market Report}

- Internal Market: Awareness, Perceptions and Impacts Report. Retrieved from: http://ec.europa.eu/public_opinion/archives/ebs/ebs_363_en.pdf, last visited on 11-07-2013. International Monetary Fund 2011

- GDP for the world and the European Union. World Economic Outlook Database: International Monetary Fund. Retrieved from:

http://Www.imf.org/external/pubs/ft/weo/2013/01/index.htm, last visited on 11-07-2013.

Leinen 2013

- Jo Leinen, For a European Social Pact 2013, Retreived from: http://www.federalist-debate. org/index.php/current-issue/comments/item/812-for-a-european-social-pact,last visited on $13-07-2013$.

\section{Van Zeben 2012}

- Josephine van Zeben, Regulatory Competence Allocation: The Missing Link in Theories of Federalism, Law Institutions and Economics in Nantere Workshop, Paris. Retrieved from http://economix.fr/pdf/seminaires/lien/Van-Zeben.pdf, last visited on 11-07-2013. 